\title{
ROTA 2030: ANALYSIS OF THE FIRST MONTHS OF RESEARCH, DEVELOPMENT AND INNOVATION PROGRAM FOR THE AUTOMOTIVE INDUSTRY
}

\author{
Brenno Soffredi Passonia, Lilian Lefol Nani Guarieiroa, Jailson B. de Andradea \\ aCentro Universitário SENAI CIMATEC, 41650-010 Salvador - BA, Brasil
}

\begin{abstract}
One of the major challenges faced by the Brazilian automotive industry has been to compare the level of competitiveness with the global economies. In 2018 Brazilian government launched Rota 2030 Program, aiming to foster research, development and innovation for the automotive industry and its production chain. This paper aimed to present a review of approved Rota 2030 programs and projects, rules of each resources coordinator, its strategic lines, counterparts, technology readiness level and participants, so that companies are able to select the best alternative to meet their needs. First 18 months results were analyzed. BRL 324 Million has been made available from taxes. Senai received more compulsory deposits and approved more projects than other coordinators showing preference of the sector for flexible programs.
\end{abstract}

Keywords: Rota 2030; Automotive Industry; Innovation.

\section{ROTA 2030: UMA ANÁLISE DOS PRIMEIROS MESES DO PROGRAMA DE FOMENTO À PESQUISA, DESENVOLVIMENTO INOV AÇÃOPARA O SETOR AUTOMOTIVO}

Resumo: Um dos grandes desafios da indústria automotiva nacional tem sido manter sua competitividade global. O governo federal criou em 2018 o Programa Rota 2030, cujo objetivo é promover a pesquisa, desenvolvimento e inovação do setor automotivo e sua cadeia. Esse artigo teve como objetivo apresentar uma revisão sobre programas e projetos aprovados e regras de cada coordenadora, considerando linhas temáticas, contrapartidas exigidas, nível de maturidade tecnológica e participantes, de forma que empresas identifiquem o que melhor atenda às suas necessidades. Os resultados dos 18 primeiros meses foram analisados, com $\mathrm{R} \$ 324$ Milhões capturados. O Senai foi o coordenador que mais recebeu recursos de impostos e aprovou mais projetos, apontando para uma preferência do setor por programas mais flexíveis.

Palavras-chave: Rota 2030; Setor Automotivo; Inovação. 


\section{INTRODUCTION}

In many respects, the automotive industry is relevant to the economy: for being a great job generator, for having an important production chain and for its investments in innovation [1].

According to MDIC (Ministry of Industry, Foreign Trade and Services), in 2015, the sector represented about $22 \%$ of Brazil's industrial GDP, employed 1.3 million people and generated US $\$ 39.7$ billion in taxes [2].

With the deepening of economic globalization, the complex and intense international competition is becoming a basic feature nowadays. Industry competitiveness is an important component of a country's comprehensive competitiveness and a key factor that affects a country's economic development. It is ultimately reflected in the ability to realize the market for products (or services), companies, and industries [3]. In this scenario, there is an undeniable need to boost technology innovation, which is an essential tool for a nation's socioeconomic development [4].

A study conducted by IPEA (Institute for Applied Economic Research) concluded that market competition and international openness are essential to pressure entrepreneurs to allocate their talent and investment resources to continuously upgrade products and processes. Improved public research and industry collaboration, supported by the injection of public funding to R\&D activities, is a priority area for business innovation to succeed and achieve worldwide competitiveness. Innovation drives productivity and economic growth of companies and countries [5].

The Brazilian automotive industry requires a strong connection with science based sectors in order to guarantee appropriate technical development. Public policies fostering R\&D are essential to enable industrial development and bring the local economy to a landing of global competitiveness [6].

Since 2012, Inovar Auto Program had been in place as a government program to increase competitiveness, technology and safety of vehicles produced and sold by the Brazilian automotive industry [7]. In Inovar Auto, R\&D investment was one of program requirements for companies to have tax reduction benefits. As Inovar Auto ended in 2017, Brazilian government launched Rota 2030 Program in 2018, considering a roadmap of vehicle safety and energy efficiency mandatory technologies, as well as fostering technological development and competitiveness for

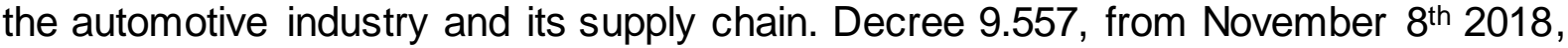
has officially established three chapters [8]:

- Chapter I: Mandatory requirements to commercialize and import new vehicles to the country;

- Chapter II: Rota 2030 Program for mobility and logistics;

- Chapter III: Tax regime of non-produced auto parts.

Even though government has officially named Rota 2030 as the second chapter alone, the three chapters have been referred to as part of Rota 2030 Program by university, industry and government itself.

This paper focus on the explanation of Rota 2030 Chapter III mechanisms and its importance for the development and R\&D investment of local automotive industry. It covers details about the rules of each priority program and project (PPP) considering main characteristics, as shown in Table 1: coordinator, strategic line, required 
counterparts, technology readiness level (TRL) metric and mandatory participants. First 18 months Program results, from January 2019 to June 2020, were identified and analyzed.

Table 1. Main Characteristics of PPPs

\begin{tabular}{|c|l|l|}
\hline Item & Characteristic & \multicolumn{1}{c|}{ Details } \\
\hline 1 & Coordinator & $\begin{array}{l}\text { Each PPP is coordinated by one institution, which receives } \\
\text { compulsory deposits from automotive companies. Coordinators } \\
\text { have autonomy to define PPP rules as long as it respects } \\
\text { government directional. }\end{array}$ \\
\hline 2 & Strategic Line & $\begin{array}{l}\text { Areas of public interest which demands investment to support } \\
\text { Brazilian industry development [9]. }\end{array}$ \\
\hline 3 & Counterpart & $\begin{array}{l}\text { Counterpart is contribution to be placed by the company taking } \\
\text { advantage of public funds for a specific R\&D project and is usually } \\
\text { split among financial and economic contribution (labor, material, } \\
\text { laboratory). It represents company share of technological risks } \\
\text { inherent to an innovation project. }\end{array}$ \\
\hline 4 & $\begin{array}{l}\text { Technology } \\
\text { Readiness }\end{array}$ & $\begin{array}{l}\text { Technology Readiness Levels are a systematic measurement } \\
\text { system that supports assessments of the maturity of a particular } \\
\text { technology and the consistent comparison of maturity among } \\
\text { different types of technology. Project TRL is an important metric to } \\
\text { determine the technological risk for which the project is submitted } \\
\text { and goes from 1 (basic research) to 9 (actual system completed } \\
\text { and incorporated to the final format through real conditions [10]. }\end{array}$ \\
\hline 5 & Participants & $\begin{array}{l}\text { Most of Rota 2030 non-repayable grants are conceded to projects } \\
\text { meeting triple helix model of university-industry-government } \\
\text { partnership, sharing risks and achievements [8]. The triple helix } \\
\text { message is that universities, firms and governments assume some } \\
\text { of the capabilities of the other, even as each maintains its primary } \\
\text { role and distinct identity [11]. }\end{array}$ \\
\hline
\end{tabular}

\subsection{Rota 2030}

Rota 2030 Program is part of federal government strategy to develop the automotive industry in Brazil. Main Program objectives are [12]:

- Improve competitiveness of local industry;

- Develop Brazilian technological capability;

- Attract investments;

- Improve vehicle safety and energy efficiency.

Independent chapters define obligations and benefits, as shown in Figure 1 [8]. 
Figure 1. Rota 2030: Obligation, Incentive, Who \& When Table

\begin{tabular}{|c|c|c|c|}
\hline & $\begin{array}{l}\text { Chapter I } \\
\text { Mandatory requirements for } \\
\text { vehicle commercialization }\end{array}$ & $\begin{array}{l}\text { Chapter II } \\
\text { Incentives on income tax } \\
\text { reductions based on R\&D } \\
\text { investment }\end{array}$ & $\begin{array}{l}\text { Chapter III } \\
\text { R\&D projects funding for the } \\
\text { automotive industry }\end{array}$ \\
\hline OBLIGATION & $\begin{array}{l}\text { Meet mandatory targets } \\
\text { of vehicle safety end } \\
\text { energy efficiency }\end{array}$ & $\begin{array}{l}\text { Invest a percentage of } \\
\text { company's revenue in R\&D }\end{array}$ & $\begin{array}{l}\text { Deposit } 2 \% \text { autoparts import } \\
\text { expense to R\&D funds }\end{array}$ \\
\hline INCENTIVE & $\begin{array}{l}\text { Target overachievement } \\
\text { provides up to } 2 \% \\
\text { manufactured products } \\
\text { tax (IPI) reduction }\end{array}$ & $\begin{array}{l}\text { Up to } 12,5 \% \text { income tax } \\
\text { reduction, proportional to } \\
\text { investment }\end{array}$ & $\begin{array}{l}\text { Non-repayable grants to } \\
\text { R\&D partnership projects }\end{array}$ \\
\hline WHO & $\begin{array}{l}\text { Automakers and } \\
\text { importers }\end{array}$ & $\begin{array}{l}\text { Any company in automotive } \\
\text { industry with R\&D iniciatives } \\
\text { (automakers and suppliers) }\end{array}$ & $\begin{array}{l}\text { Automakers, suppliers, } \\
\text { universities and } \\
\text { institutes of science and } \\
\text { technology (IST) }\end{array}$ \\
\hline WHEN & $\begin{array}{l}\text { Fleet measurement } \\
\text { starting in Oct } 2021\end{array}$ & Dec 2018 to Nov 2023 & Jan 2019 to Dec 2023 \\
\hline
\end{tabular}

Elaborated by the authors

Chapter I establishes levels of energy efficiency and safety technologies that must be gradually incorporated into vehicle fleets by manufacturers and importers, starting in Oct 2021. Furthermore, for the vehicles achieving targets above minimum to comply, up to $2 \%$ reduction on tax on manufactured products (IPI) will be granted. Chapter II establishes that up to $12.5 \%$ of total amount invested in R\&D projects will be deductible from income tax to pay for the firms investing a minimum percentage of its revenue in R\&D projects in Brazil. Application for this chapter is optional, but the company that applies then has the obligation of minimum R\&D investment. Chapter III exempts importation of non-locally produced auto parts from import tax (II), with the counterpart for the importer to deposit the $2 \%$ equivalent expense in research, development and innovation partnership programs. The referred programs, known as PPP, support industrial and technological development for the automotive industry and its supply chain [8].

Thus, this paper was carried out through bibliographic review in order to point out the importance of RD\&I investments for the competitiveness of automotive industry and characterize how Rota 2030 Program can contribute for that. A deep investigation on Rota 2030 Chapter III has been made to characterize its mechanis ms so automotive companies can take most advantage of Program benefits, while fulfilling their obligations.

\section{METHODOLOGY}

Bibliographic review was based on Brazilian government legal publications (decrees, laws and official communications), studies on RD\&I conducted by other authors and Brazilian institutes and Program results disclosed by the institutes who coordinate Rota 2030 priority programs and projects. It has been also based on seminars, congresses, meetings with coordinators, universities, Institutions of Science and Technology (ICT) and private companies. The paper shows all the information collected from those interfaces. A consolidation of Rota 2030 Chapter III 
achievements, approved projects, boosted resources and affected companies, universities and ICTs is presented.

\section{RESULTS AND DISCUSSION}

Chapter III brings a new format of government funding for R\&D projects. Import tax of non-locally produced auto parts has been reduced from 14-18\% to zero, however importers must deposit $2 \%$ equivalent in PPP funds to support industrial and technological development of automotive industry [8]. With that mechanism, MDIC has estimated that PPP funds will collect BRL 200 million from automotive industry (automakers and suppliers) per year, to fund projects [13].

In March $12^{\text {th }} 2019$, an ordinance of Ministry of Economy (ME) defined the Management Board, with the responsibility of creating rules for Rota 2030 financial resources usage, defining strategic lines for PPPs and approving Brazilian institutions as PPP coordinators [9]. Quantity of representatives by sector with seats in Management Board is shown in table below.

Table 2. Reps in Management Board [9]. Elaborated by the authors

\begin{tabular}{|c|c|c|c|c|}
\hline \multirow{3}{*}{ Sector Rep } & \multirow{3}{*}{ Background } & \multicolumn{3}{|c|}{ Quantity of Reps } \\
\hline & & \multirow[b]{2}{*}{ Total } & \multicolumn{2}{|c|}{ Seats Split } \\
\hline & & & Members & $\begin{array}{c}\text { Altern. } \\
\text { Members }\end{array}$ \\
\hline \multirow{3}{*}{ Government } & Ministry of Economy (ME) & 7 & 1 (President) +3 & 3 \\
\hline & $\begin{array}{l}\text { Ministry of Science, Technology, Innovation and } \\
\text { Communication (MCTIC) }\end{array}$ & 6 & 3 & 3 \\
\hline & Sub-Total & 13 & & \\
\hline \multirow{5}{*}{ Business } & $\begin{array}{l}\text { National Association of Automotive Vehicles } \\
\text { Manufacturers (ANFAVEA) }\end{array}$ & 2 & 1 & 1 \\
\hline & $\begin{array}{l}\text { National Association of Brazilian Auto Parts } \\
\text { manufacturers (Sindipeças) }\end{array}$ & 2 & 1 & 1 \\
\hline & $\begin{array}{l}\text { Brazilian Association of Private Equity and } \\
\text { Venture Capital (ABVCAP) }\end{array}$ & 1 & 1 & N/A \\
\hline & $\begin{array}{l}\text { National Association of Entities Promoting } \\
\text { Innovative Enterprises (Anprotec) }\end{array}$ & 1 & $\mathrm{~N} / \mathrm{A}$ & 1 \\
\hline & Sub-Total & 6 & & \\
\hline \multirow{2}{*}{ Labor Union } & General Workers' Union (UGT) & 2 & 1 & 1 \\
\hline & Sub-Total & 2 & & \\
\hline \multirow{3}{*}{$\begin{array}{l}\text { Scientific } \\
\text { Com munity }\end{array}$} & $\begin{array}{l}\text { Brazilian Society of Mechanical Sciences and } \\
\text { Engineering (ABCM) }\end{array}$ & 1 & 1 & N/A \\
\hline & $\begin{array}{l}\text { Brazilian Association of } \\
\text { automotive engineering (AEA) }\end{array}$ & 1 & $\mathrm{~N} / \mathrm{A}$ & 1 \\
\hline & Sub-Total & 2 & & \\
\hline & Total Representatives & 23 & & \\
\hline
\end{tabular}

In May 2019, Management Board nominated five working groups (GT) to lead five strategic lines technical discussions. GTs worked on 33 PPPs previously submitted by ICTs, universities and Brazilian agencies. The five strategic lines are [9]:

1- Increased productivity in the automotive supply chain;

2- Process automation, industrial connectivity and advanced manufacturing;

3- Increased investments in research, development and innovation;

4- Strengthening of the tooling and mold chain for automotive products;

5- Technologies for biofuels, vehicle safety and alternative propulsion. 
GTs analyzed PPPs based on criteria shown in table 3, a courtesy of ME. Most importantly, PPPs must foster industry development by benefiting all Brazilian regions, leveraging private counterparts and sparking automotive industry interest.

Table 3. PPP Assessment Criteria. Elaborated by the authors based on information from ME

\begin{tabular}{|c|l|}
\hline Group & \\
\hline \multirow{2}{*}{ Premise } & Program coverage \\
\cline { 2 - 2 } & Capillarity of candidate coordinator \\
\hline \multirow{3}{*}{ Coordinator } & Institution has shown experience in the area of interest? \\
\cline { 2 - 2 } & Institution has as project management structure? \\
\hline \multirow{4}{*}{ Program } & Budget, timing and controls are accurate? \\
\cline { 2 - 2 } & Ability to leverage private counterparts? \\
\cline { 2 - 2 } & Program raises industry interest? \\
\cline { 2 - 2 } & Program promotes social, economic and technological impact? \\
\cline { 2 - 2 } & Program fosters integration among ICT, university, start-up and company? \\
\hline
\end{tabular}

Based on GTs recommendation, four institutions have been approved to coordinate five Programs (known as coordinators), as shown in Table 4.

Table 4. Priority Programs Approved

\begin{tabular}{|c|c|c|c|c|c|c|}
\hline Line & Coordinator & Program & $\begin{array}{l}\text { Enterprises } \\
\text { Counterpart }\end{array}$ & Participants (minimum) & $\begin{array}{l}\text { Budget } \\
\text { (BRL) }\end{array}$ & TRL \\
\hline$T$ & SENAI & $\begin{array}{l}\text { Innovation to } \\
\text { Supply Chain }\end{array}$ & $\begin{array}{l}\text { Financial: } 20.5 \% \\
\text { Economic: } 20.0 \%\end{array}$ & $\begin{array}{l}\text { - } 1 \text { Institute Senai of } \\
\text { Innovation } \\
-2 \text { suppliers per } \\
\text { automaker }\end{array}$ & $2 \mathrm{M}-8 \mathrm{M}$ & $6-9$ \\
\hline \multirow[t]{2}{*}{ TाI } & \multirow[t]{2}{*}{ EMBRAPII } & $\begin{array}{l}\text { M1: Company + } \\
\text { Embrapii ICT }\end{array}$ & Financial: $67 \%$ & $\begin{array}{l}\text { - } 1 \text { company } \\
\text { - } 1 \text { Embrapii ICT }\end{array}$ & $\mathrm{N} / \mathrm{A}$ & $3-6$ \\
\hline & & $\begin{array}{l}\text { M2: Company + } \\
\text { Small Comp. }{ }^{*}+ \\
\text { Embrapii ICT }\end{array}$ & Financial: $50 \%$ & $\begin{array}{l}-1 \text { company } \\
-1 \text { small comp.* } \\
-1 \text { Embrapii ICT }\end{array}$ & $\mathrm{N} / \mathrm{A}$ & $3-6$ \\
\hline IV & FUNDEP & $\begin{array}{l}\text { Strengthening of } \\
\text { the Tooling and } \\
\text { Mold Chain }\end{array}$ & Economic: $30 \%$ & $\begin{array}{l}\text { At least } 1 \mathrm{ICT} \text {, but more } \\
\text { companies and ICTs w ill } \\
\text { rank project higher }\end{array}$ & $1 \mathrm{M}-6 \mathrm{M}$ & $2-7$ \\
\hline V & FUNDEP & $\begin{array}{l}\text { Biofuels, Vehicle } \\
\text { Safety \& } \\
\text { Propulsion }\end{array}$ & Economic: $30 \%$ & $\begin{array}{l}-1 \text { ICT } \\
-1 \text { tool maker } \\
-1 \text { tool user }\end{array}$ & $1 \mathrm{M}-4 \mathrm{M}$ & $\begin{array}{c}1-9 \\
\text { (higher's } \\
\text { better) }\end{array}$ \\
\hline- & \begin{tabular}{l|} 
FINEP \\
(Transversal)
\end{tabular} & Rota 2030 & $\begin{array}{l}\text { Financial: } \\
33 \% \text { (medium comp. }^{\star \star} \text { ) } \\
50 \% \text { (large comp.***) }^{*}\end{array}$ & $\begin{array}{l}\text { Company alone allow ed, } \\
\text { better conditions for ICTs } \\
\text { partnership }\end{array}$ & $\begin{array}{c}200 \mathrm{~K}- \\
3 \mathrm{M}\end{array}$ & $\begin{array}{c}1-9 \\
\text { (higher's } \\
\text { better) }\end{array}$ \\
\hline
\end{tabular}

Line II didn't have any PPP approved. National Service for Industrial Training (Senai), Brazilian Company for Research and Industrial Innovation (Embrapii), Foundation for Research Development (Fundep) and Financier of Studies and Projects (Finep) were the four approved coordinators, Fundep having coordination of two PPPs (line IV and V). Official approval was granted on September 2019, nine months after Chapter III mechanism kick off. Until then, importers should deposit the $2 \%$ mandatory contribution into a Ministry account. After PPP approvals, resources from Ministry account were equally shared among the five PPPs. Importers could then monthly choose which PPP to deposit contribution at, or split monthly contribution into more than one PPP. Deadline for importers to deposit contribution into chosen PPP is 2 months counting from month of auto part importation [8]. Chapter III source of funds is formed by the $2 \%$ industry compulsory contribution as an alternative to the regular 14 to $18 \%$ import tax, as shown in figure 2 below. 
Figure 2: Chapter III Source of Funds

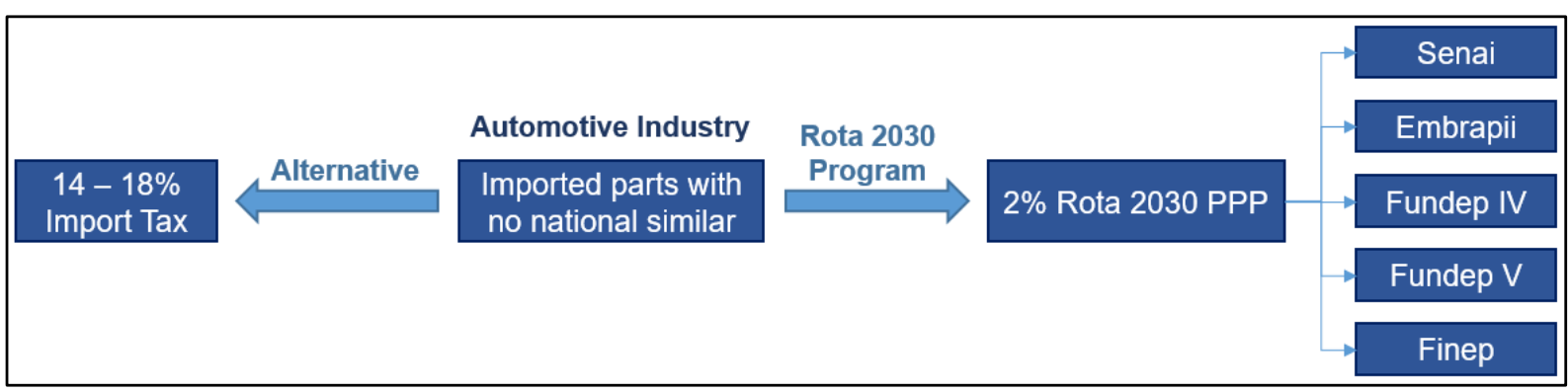

Elaborated by the authors

Any automaker or supply chain may participate on funded projects, regardless contributing with the $2 \%$ deposit. Companies do not need to apply for Rota Chapter II in order to participate on projects. Projects applying for PPP funding must be submitted and led by ICTs or universities, in partnership with automakers and suppliers [9]. Decree 9.557 established Rota 2030 Program in November 2018. First partnership project was approved in February 2020. A process timeframe is shown in figure 3.

Figure 3. Chapter III Timeframe

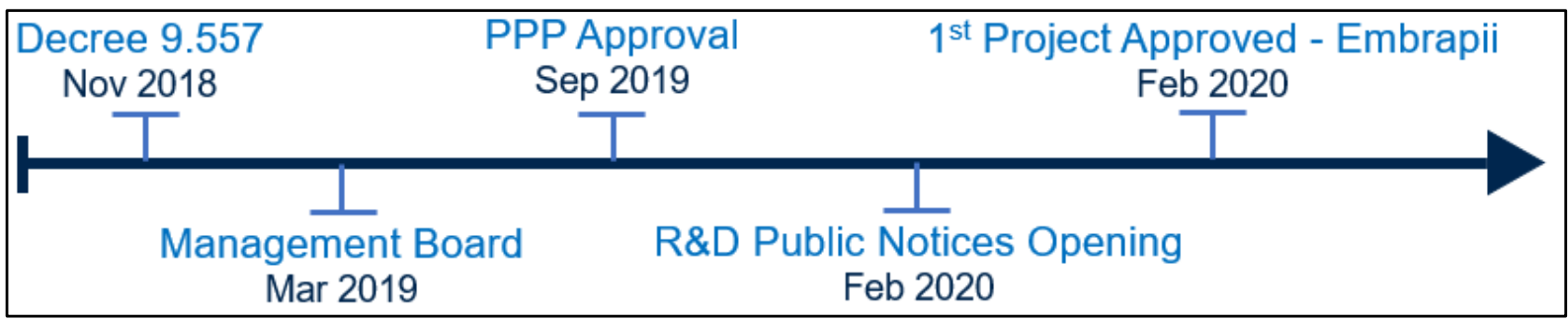

Elaborated by the authors

A summary of industry tax deposit and approved projects is shown in table 5 .

Table 5: Coordinators Comparison (Courtesy of Coordinators - cutoff Jun 2020)

\begin{tabular}{|c|c|c|c|}
\hline Coordinator & Detailed Program Modality & Projects Approved & Industry Deposit \\
\hline \multirow{4}{*}{ SENAI } & $\begin{array}{l}\text { Hands-on: Lean Manufacturing \& } \\
\text { Digitalization Consultant }\end{array}$ & 54 consultant projects & \multirow{4}{*}{ BRL 82 Million } \\
\hline & Industrial Alliance & 5 R\&D projects & \\
\hline & Industrial Entrepreneurship & 1 Project & \\
\hline & Master Business Innovation (MBI) & $\begin{array}{l}50 \text { vacancies sharedamong } \\
\text { donor companies, proportional to } \\
\text { contribution }^{\star \star}\end{array}$ & \\
\hline \multirow[b]{2}{*}{ EMBRAPII } & M1: Company + Embrapii ICT & 12 projects & \multirow[b]{2}{*}{ BRL 52 Million } \\
\hline & $\begin{array}{l}\text { M2: Company + Small Company }{ }^{*} \\
\text { Embrapii ICT }\end{array}$ & 1 project & \\
\hline FUNDEP IV & $\begin{array}{l}\text { Strengthening of the Tooling and } \\
\text { Mold Chain }\end{array}$ & $\begin{array}{l}\text { R\&D public notes open for } \\
\text { projects submission }\end{array}$ & BRL 56 Million \\
\hline FUNDEP V & $\begin{array}{l}\text { Biofuels, Vehicle Safety and } \\
\text { Alternate Propulsion }\end{array}$ & 16 projects & BRL 79 Million \\
\hline \multirow{2}{*}{$\begin{array}{c}\text { FINEP } \\
\text { Transversal }\end{array}$} & Entrepreneurship & Public notes not open & \multirow{2}{*}{$\begin{array}{l}\text { BRL 45 Million } \\
\text { (as of May 2020) }\end{array}$} \\
\hline & Start-Up & 2 projects & \\
\hline
\end{tabular}

Elaborated by the authors *Small company: company with gross operating revenue up to BRL 90 Million / year

**For each BRL 450 Thousand contribution, company is offered one MBI vacancy. Counting period from Sep 2019 to Jan 2020

\section{CONCLUSION}

Rota 2030 is a game changer for automotive industry development and competitiveness due to its R\&D projects funding mechanism. Management board has representatives from several sectors (Government, Business, Labor Union and Scientific Community) to guarantee different points of view are captured. In 18 months 
of operation, BRL 324 Million have been raised as industry tax deposit in Chapter III. Senai has approved more projects and received more deposit than other coordinators. Reason for that is Senai counterpart flexibility and program modalities diversification. Fundep $\mathrm{V}$ has received relevant deposit amount due to automotive interest in biofuels and safety areas, aligned with non-obligation of financial counterpart. Fundep IV has not received as much deposit as Senai and Fundep $V$ probably due to difficulty in engaging toolmakers. Mandatory financial counterpart has been a barrier for companies to support Embrapii Program, probably the reason why Embrapii has not received as much deposit as others. Finep had not published its Entrepreneurship public note by the time this paper was written, so it has not been companies' deposit first choice. Each coordinator requires different quantity of participating companies and Institutions of Science and Technology, counterparts and TRL, thus company elaborating projects must pay attention to coordinator rules. All observed data points to a clear advice from automotive sector to the coordinators: the programs have to be flexible to help a complex industry and supply chain to take advantage of the offered resources and promote local industry growth.

\section{REFERENCES}

${ }^{1}$ DAUDT, Gabriel Marino; WILLCOX, Luiz Daniel. Indústria automotiva. 2018.

${ }^{2}$ MDIC. Setor Automotivo. Ministério da Economia, Comércio Exterior e Serviços, Brasilia, 2018. Available at: <http://www.mdic.gov.br/index.php/competitividade-industrial/setorautomotivo >. Accessed on: 11 Jul. 2020

${ }^{3}$ YUAN-QIANG, Lian. TS fuzzy prediction on competitive structure model and evaluation system of emerging industry innovation alliance. Cognitive Systems Research, v. 52, p. 192-197, 2018.

${ }^{4}$ HALLAK, Augusto Teixeira; LOZOUET, Louis. Propriedade Intelectual e Incentivos Fiscais à Inovação: Ferramentas para maximização do retorno sobre investimentos em Pesquisa, Desenvolvimento e Inovação. ABGI and Venturini IP, Belo Horizonte, 07 jul. 2020. Available at: $<$ https://brasil.abgi-group.com/wp-content/uploads/2020/07/Artigo_Incentivos_vs_PI_B31-1.pdf>. Accessed on: 11 Jul. 2020

${ }^{5}$ ZUNIGA, Pluvia et al. Conditions for innovation in Brazil: a review of key issues and policy challenges. IPEA Discussion Paper, Brasilia, nov. 2016.

${ }^{6}$ DA SILVA, Almir Cléydison Joaquim; BORTOLOTTI, Mônica Aparecida; SHIMA, Walter Tadahiro. Sectoral patterns of technical change and innovation promotion in the Brazilian industry: considerations about the automotive sector. Revista Catarinense de Economia, v. 1, n. 2, 2018

7 DE MELLO, Adriana Marotti; MARX, Roberto; MOTTA, Flavia Gutierrez. A preliminary analysis of Inovar Auto impact on the Brazilian Automotive Industry R\&D activity. RAl Revista de Administração e Inovação, v. 13, n. 1, p. 22-28, 2016.

${ }^{8}$ BRASIL. Decree n. 9.557, 8 nov. 2018. Minimum requierements to commercialize vehicles in the country, Rota 2030 Program - mobility and logistics - and tax regime of non-produced auto parts, Brasília, nov. 2018.

${ }^{9}$ BRASIL. Ordinance of the Ministry of Economy n. 86, 12 mar. 2019. Functioning of the Management Board, Brasília, mar. 2019.

${ }^{10}$ MANKINS, John C. Technology readiness levels. White Paper, April, v. 6, p. 1995, 1995.

11 ETZKOWITZ, H. University-Industry-Government: The Triple Helix Model of Innovation. Newcastle University. Newcastle upon Tyne. 2007.

${ }^{12}$ MDIC. Setor Automotivo. Ministério da Economia, Comércio Exterior e Serviços, Brasilia. Available $\quad$ at: $\quad<$ http://www.mdic.gov.br/index.php/competitividade-industrial/setorautomotivo/rota2030>. Accessed on: 12 Jul. 2020

${ }^{13}$ MDIC. Setor Automotivo. Ministério da Economia, Comércio Exterior e Serviços, Brasilia. Available at: <http://www.mdic.gov.br/index.php/ultimas-noticias/3951-conselho-do-rota-2030lanca-programas-prioritarios-da-nova-politica-do-setor-automotivo>. Accessed on: 14 Jul. 2020 